\title{
PEMODELAN CITRA AKUIFER MENGGUNAKAN METODE GEOLISTRIK
}

\author{
Jeris Habfrons Wiatri Djereng ${ }^{1}$, I Nengah Simpen ${ }^{1}$, I Wayan Gede Suharta ${ }^{1^{*}}$
}

${ }^{1}$ Jurusan Fisika, Fakultas Matematika dan Ilmu Pengetahuan Alam, Universitas Udayana, Kampus Bukit Jimbaran, Badung, Bali Indonesia 80361.

*Email : suharta@unud.ac.id

\begin{abstract}
Abstrak
Telah dilakukan penelitian mengenai pemodelan citra akuifer menggunakan metode geolistrik. Penelitian ini dilakuan pada 7 kondisi dengan pengambilan data satu lintasan pada tiap kondisi yaitu kondisi tanpa diberi model, kondisi model flat tidak diberi air dan diberi air, kondisi akuifer cekung tidak diberi air dan diberi air, serta kondisi akuifer berurat tidak diberi air dan diberi air ini sehingga didapatkan tampilan citra dari hasil inversi data resistivitas menggunakan Res2dinv. Pemodelan citra pada akuifer flat dengan menggunakan metode geolistrik didapatkan bentuk citra berupa lapisanlapisan citra dengan warna yang berbeda dimana hal ini dikarenakan susunan bahan serta kandungan air yang berbeda. Pemodelan citra pada akuifer cekung dengan menggunakan metode geolistrik didapatkan citra akuifer terletak pada kedalaman $15-30 \mathrm{~cm}$ dengan warna biru dikarenakan pada daerah ini kandungan airnya lebih banyak dibandingkan daerah lainnya. Pemodelan citra akuifer pada berurat dengan menggunakan metode geolistrik didapatkan tampilan citra berupa dua titik akuifer dengan warna biru yang terpisah dimana merupakan dua sumber air. Pada pemodelan citra akuifer menggunakan metode geolistrik ini nilai resistivitas daerah akuifer lebih rendah dibandingkan daerah lainnya hal ini ditunjukkan dengan warna citra biru muda hingga pekat.
\end{abstract}

Kata kunci: geolistrik, akuifer, resistivitas, Res2dinv.

\begin{abstract}
Has been done research on modeling the image of the aquifer using geoelectric method. This research was conducted on 7 conditions by taking one data at each condition there is condition without being given a model, model conditions flats have not given water and by water, aquifer conditions concave not given water and by water, and aquifer conditions veined not given water and by water this so can get to see the image data inversion results of resistivity using Res2dinv. Modeling the aquifer flat using geoelectric method obtained the image in the form of layers of images with different colors in which this is due to the material composition and water content are different. Modeling the concave aquifer using geoelectric obtained the aquifer at a depth of 15-30 cm with blue color because in this area the water content is more than other areas. Modeling a branched aquifer using geoelectric method obtained the image in the form of two points aquifer detached in blue, this is two water sources. In the image modeling of aquifers using geoelectric method the resistivity value lower aquifer region compared to other regions as indicated by the color of light blue until dark.
\end{abstract}

Keywords: geoelectric, aquifer, resistivity, Res2dinv.

\section{PENDAHULUAN}

Aktifitas manusia selalu membutuhkan air, dimulai dari kebutuhan rumah tangga sampai dengan kebutuhan industri. Tingginya kebutuhan manusia terhadap air mendorong untuk selalu dilakukannya eksplorasi 
sumber air. Bermacam-macam teknologi berkembang untuk menganalisis keadaan bawah permukaan. Metode geofisika memanfaatkan prinsip - prinsip fisika untuk menggambarkan pola di bawah permukaan bumi. Salah satunya ialah metode geolistrik, metode ini juga sering dimanfaatkan untuk eksplorasi sumber air. Kegiatan eksplorasi sumber air selalu diikuti dengan kuantitas air yang didapatkan. Kuantitas air ditunjukkan oleh pola akuifer yang didapatkan. Akuifer flat, akuifer cekung serta akuifer berurat menghasilkan kuantitas air yang berbeda.

Metode geolistrik resistivitas merupakan metode yang mempelajari sifat aliran listrik di dalam batuan di bawah permukaan tanah. Metode geolistrik resistivitas digunakan karena resistivitas dari batuan sangatlah sensistif terhadap kandungan airnya. Pentingnya digunakan metode geolistrik resistivitas karena metode ini merupakan satu-satunya metode yang efektif mengetahui sifat konduktifitas suatu lapisan.

Akuifer adalah lapisan bawah tanah yang mengandung air dan mampu mengalirkan air. Hal ini disebabkan karena lapisan tersebut bersifat permeable yang mampu mengalirkan air baik karena adanya pori-pori pada lapisan tersebut ataupun memang sifat dari lapisan batuan tertentu (Prihastiwi, 2016).

Pemodelan akuifer merupakan kajian secara menyeluruh tentang kondisi lapisan atau formasi geologi yang diaplikasikan secara konseptual dalam model tiga dimensi yang bertujuan untuk memberikan gambaran pola dari akuifer. Penelitian ini perlu dilakukan karena dapat memberikan gambaran mengenai pola akuifer terbaik yang memudahkan aktivitas manusia dalam pengeboran sumber air dan juga merupakan pengembangan dari teori geolistrik serta memudahkan penelitian lebih lanjut mengenai pemodelan akuifer flat, pemodelan akuifer cekung, dan pemodelan akuifer berurat.

\section{TINJAUAN PUSTAKA}

\subsection{Akuifer, Akuitar, dan Akuiklud}

Akuifer adalah lapisan bawah tanah yang mengandung air dan mampu mengalirkan air. Akuitar adalah lapisan atau formasi batuan semi kedap yang mampu mengalirkan air tetap dengan laju yang sangat lambat jika dibanding dengan akuifer. Akuiklud merupakan lapisan atau formasi batuan yang mengandung air tetapi dalam kondisi alami tidak mampu mengalirkannya (Krussemen \& Ridder, 1970).

\subsection{Metode Geolistrik}

Metode geolistrik merupakan salah satu metode geofisika yang mempelajari sifat aliran listrik di dalam bumi dan bagaimana cara mendeteksinya di dalam bumi maupun permukaan bumi. Dalam hal ini meliputi pengukuran potensial, arus dan medan elektromagnetik yang terjadi baik secara alamiah ataupun akibat injeksi arus ke dalam bumi. Ada beberapa macam metode geolistrik yaitu metode potensial diri, arus telluric, magnetotelluric, IP (Indiced Polarization), resistivitas (tahanan jenis) dan lain-lain. Metode geolistrik resistivitas yaitu metode pengambilan data dengan cara arus listrik diinjeksi dengan frekuensi rendah ke permukaan bumi yang kemudian diukur beda potensial di antara dua buah elektroda potensial (Geocis, 2016).

\subsection{Teknik Eksplorasi Metode Resistivitas dengan Software Res2dinv}

Konfigurasi Wenner merupakan salah satu konfigurasi yang sering digunakan dalam eksplorasi geolistrik dimana 
pengukurannya dilakukan dengan cara memasang elektroda arus dan potensial pada satu garis lurus dengan spasi tetap, kemudian semua elektroda dipindahkan atau digeser sepanjang permukaan sesuai dengan arah yang telah ditentukan sebelumnya. Selanjutnya setiap posisi elektroda akan didapatkan harga resistivitas semu. Dengan membuat peta kontur resistivitas semu akan diperoleh pola kontur yang menggambarkan adanya resistivitas yang sama. Software Res2dinv adalah sebuah perangkat lunak komputer yang secara otomatis menentukan model resistivitas 2-D untuk bawah permukaan dari hasil pengukuran metoda resistivitas. Model 2-D menggunakan program inversi yang terdiri dari kotak persegi. Susunan kotak persegi ini terikat oleh distribusi titik datum dalam psuedosection. Subrutin dari pemodelan ke depan digunakan untuk menghitung nilai resistivitas semu dan teknik optimasi leastsquarenon linier digunakan untuk rutin inversi. Format input ke dalam perangkat lunak di atas harus dalam notepad atau wordpad.

\section{METODE PENELITIAN}

Penelitian ini menggunakan beberapa alat yaitu resistivitymeter model Skillpro, elektroda, kabel sebagai penghubung elektroda dan resistivity meter, aki, laptop/computer, software Res2dinv dan SiBeRTools, meteran dan alat tulis. Bahan yang digunakan dalam penelitian ini adalah pemodelan akuifer yang tersusun atas air, tanah, semen atau bahan anti serap serta pasir. Bahan-bahan yang digunakan dibentuk pada penampang berukuran 240x120x60 $\mathrm{cm}^{3}$ menjadi tiga model akuifer yaitu model akuifer flat, model akuifer cekung serta model akuifer berurat. Pengambilan data dilakukan dengan menggunakan alat
SkillPro, elektroda yang digunakan lebih banyak karena cukup dengan menempatkan elektroda pada setiap titik dengan jarak $a$ sepanjang lintasan, maka SkillPro akan secara otomatis menentukan nilai perpindahan elektroda.

Langkah-langkah pengambilan data sebagai berikut:

1. Merangkai peralatan seperti diperlihatkan pada Gambar 3.1.

2. Mengukur panjang lintasan penelitian.

3. Menentukan spasi awal yaitu $\mathrm{m}(\mathrm{n}=1)$ dan menandai dengan pasak. Pengukuran ini disesuaikan dengan aturan konfigurasi Wenner seperti diperlihatkan pada Gambar 3.2.

4. Memasang dua puluh empat elektroda di tempat yang sudah ditandai.

5. Kedua puluh empat elektroda tersebut dihubungkan dengan resistivity meter dengan menggunakan kabel penghubung.

6. Resistivitymeter diaktifkan dan diatur jarak/spasi elektroda sesuai yang ditentukan, jumlah elektroda yg digunakan, serta berapa level atau lapisan yang diinginkan.

7. Kemudian hubungkan resistivity meter dengan aki untuk selanjutnya dilakukan injeksi arus listrik dalam tanah.

Setelah dilakukan injeksi arus maka data akan terekam oleh SkillPro berupa nilai arus listrik (I), beda potensial (V) yang ditimbulkan oleh penginjeksian arus listrik ke dalam permukaan tanah dan nilai resistivitas. Data hasil penelitian selanjutnya diolah dengan menggunakan software SiBeRTools dan Res2dinv. SibERTools digunakan untuk export file berupa *.d2d ke file berupa *.dat sehingga bisa dibaca oleh Res2dinv. Selanjutnya data diolah menggunakan Res2dinv untuk inversi data sehingga menampilkan citra. 


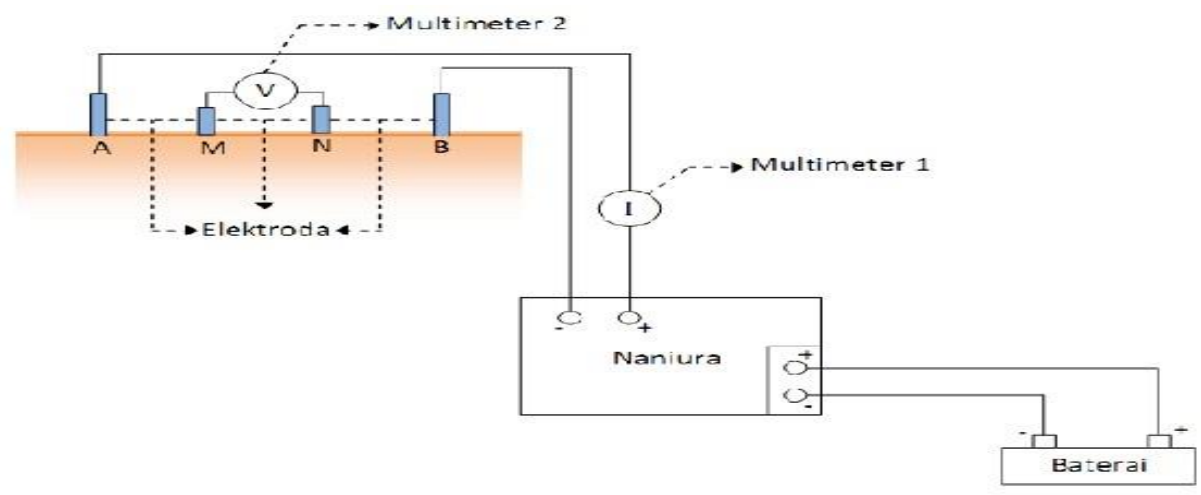

Gambar 3.1. Rangkaian set geolistrik.

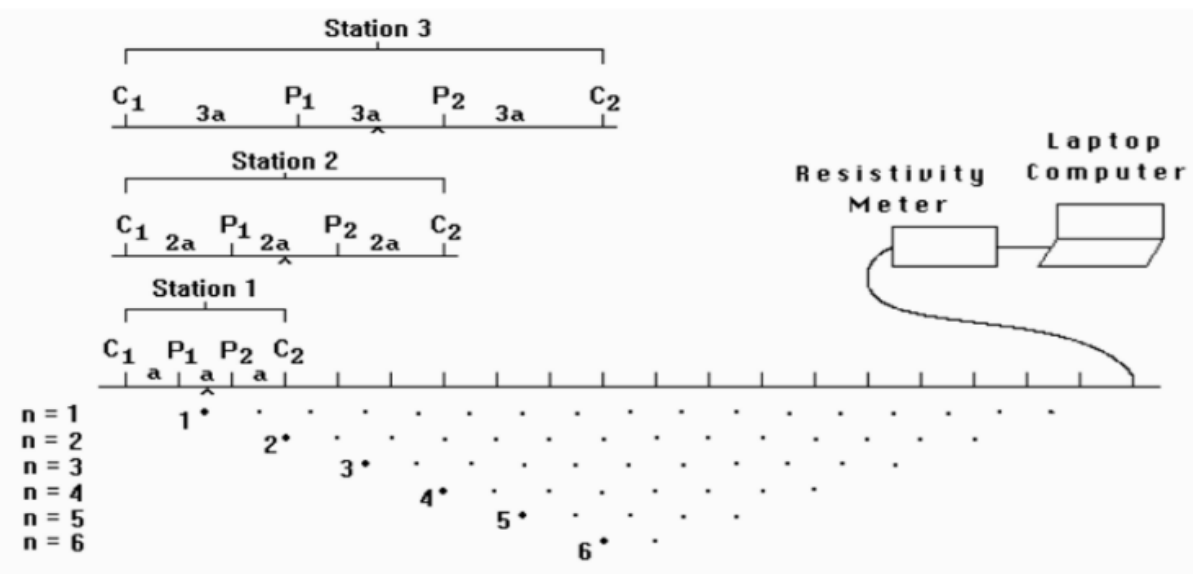

Gambar 3.2. Pengambila data dengan Konfigurasi Wenner (Loke, 2000).

Setelah dilakukan injeksi arus maka data akan terekam oleh SkillPro berupa nilai arus listrik (I), beda potensial (V) yang ditimbulkan oleh penginjeksian arus listrik ke dalam permukaan tanah dan nilai resistivitas. Data hasil penelitian selanjutnya diolah dengan menggunakan software SiBeRTools dan Res2dinv. SibERTools digunakan untuk exportfile berupa *.d2d ke file berupa *.dat sehingga bisa dibaca oleh Res2dinv. Selanjutnya data diolah menggunakan Res2dinv untuk inversi data sehingga menampilkan citra.

\section{IV.HASIL DAN PENGAMATAN}

Pemodelan respon citra akuifer flat, cekung dan berurat dilakukan dengan pengambilan data 1 lintasan pada setiap pemodelan yang terdiri dari kondisi tanpa diberi model, kondisi model flat tidak diberi air dan diberi air, kondisi akuifer cekung tidak diberi air dan diberi air, serta kondisi akuifer berurat tidak diberi air dan diberi air. Pada pemodelan respon ketujuh kondisi ini pada setiap lintasannya terdiri dari 84 data pengukuran atau datum points menggunakan sebanyak 24 elektroda dengan jarak antar elektroda $10 \mathrm{~cm}$.

Hasil pengolahan dari software Res2dinv diperlihatkan pada Gambar 4.1. menunjukkan bahwa Lintasan 1 tidak ada model dengan nilai resistivitas minimum $14,40 \Omega \mathrm{m}$ dan resistivitas maksimum sebesar $170,87 \Omega \mathrm{m}$. Nilai eror pada inversi data pemodelan flat tanpa diberi air sebesar $1,87 \%$. Adanya perbedaan warna citra pada hasil inversi datakarena adanya perbedaan tingkat kelembaban pada tanah. 


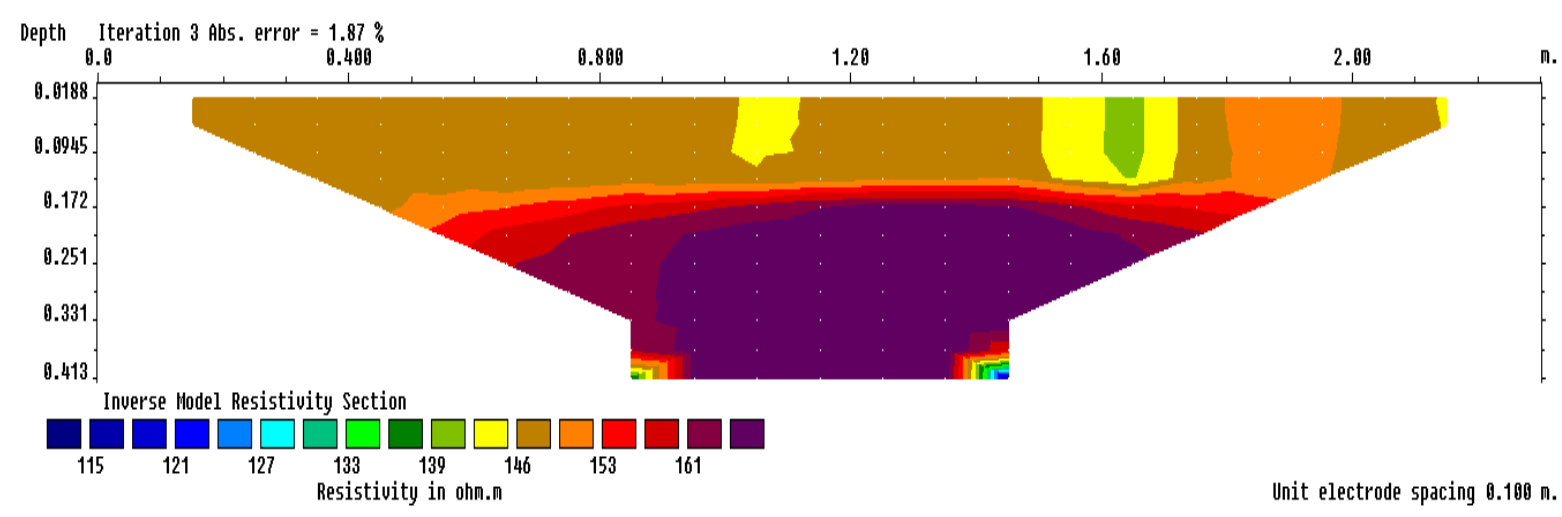

Gambar 4.1. Hasil pengolahan data Res2dinv pada Lintasan 1 kondisi tanpa model engan Konfigurasi Wenner.

\subsection{Akuifer Flat}

Hasil pengolahan dari software Res2dinv diperlihatkan pada Gambar 4.2. menunjukkan bahwa akuifer terdiri dari beberapa lapisan yang berbeda dimana ditunjukkan dengan adanya perbedaanperbedaan warna citra. Pada tampilan citra ini warna biru tua atau pekat menunjukkan tingkat kelembaban yang lebih tinggi dibandingkan warna citra lainnya. Berdasarkan hasil pengolahan data Res2dinv pada Lintasan 2 model flat sebelum diberi air terletak pada kedalaman 12-25 cm dengan warna citramerah sampai dengan ungu pekat dan pada Lintasan 3 model flat setelah diberi air dengan warna citra biru muda sampai dengan biru tua. Nilai resistivitas pada kondisi sebelum diberi air lebih besar dibandingkan setelah diberi air yaitu pada Lintasan 2 nilai resistivitas minimum sebesar $147,03 \Omega \mathrm{m}$ dan resistivitas maksimumnya sebesar 364,73 $\Omega \mathrm{m}$ sedangkan pada Lintasan 3 nilai resistivitas minimum $83,12 \Omega$ m dan resistivitas maksimumnya148,72 $\Omega \mathrm{m}$. Besarnya nilai eror pada tampilan citra menunjukkan banyaknya variasi data yang didapatkan pada saat penelitian. Dalam aktivitas manusia, gambaran pola akuifer flat lebih memudahan untuk pengeboran sumber air. Pola akuifaer flat memungkinkan untuk melakukan pengeboran di titik mana saja karena dalam hal ini, di titik mana pun akan mendapatkan air dengan volume yang sama besarnya dengan titik lainnya.

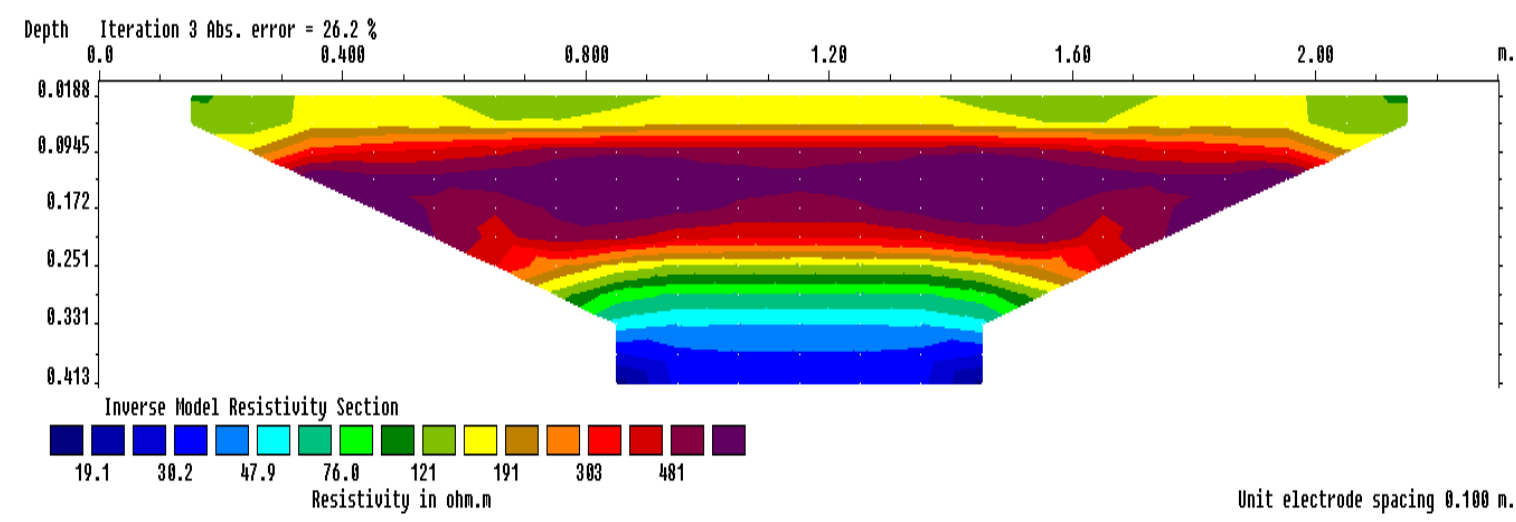

Gambar 4.2. Hasil pengolahan data Res2dinv pada Lintasan 2 dan Lintasan 3 kondisi akuifer flat sebelum diberi air dan setelah diberi air dengan Konfigurasi Wenner. 


\subsection{Akuifer Cekung}

Hasil pengolahan dari software Res2dinv diperlihatkan pada Gambar 4.3 menunjukkan bahwa kondisi pemodelan cekung tidak diberi air dan diberi air terletak pada kedalaman 15-30 $\mathrm{cm}$ pada Lintasan 4 dengan warna citra kuning sampai ungu pekat dan Lintasan 5 dengan warna citra biru muda sampai biru tua. Nilai resistivitas pada kondisi sebelum diberi air lebih besar dibandingkan setelah diberi air yaitu pada Lintasan 4 nilai resisitivitas minimum pada pemodelan ini $127,03 \Omega \mathrm{m}$ dan maksimum resistivitas sebesar 408,83 $\Omega \mathrm{m}$ sedangkan pada Lintasan 5 nilai resisitivitas minimum pada pemodelan ini $63,74 \Omega \mathrm{m} \quad$ dan maksimum resistivitas sebesar 147,92 $\Omega \mathrm{m}$. Padahasil pengolahan data ini, tampilan warna-warna citra yang sama menunjukkan tersusun atas bahan serta tingkat kelembaban yang sama. Warna biru tua atau pekat menunjukkan tingkat kelembaban yang lebih tinggi dibandingkan warna citra lainnya. Besar kecilnya nilai eror bergantung pada variasi data yang didapatkan pada saat penelitian. Dalam aktivitas manusia, berbeda halnya dengan pola akuifer flat untuk mendapatkan volume air yang besar pada akuifer cekung, pengeboran sumber air hanya dapat dilakukan pada titik-titik tengah dari akuifer ini.

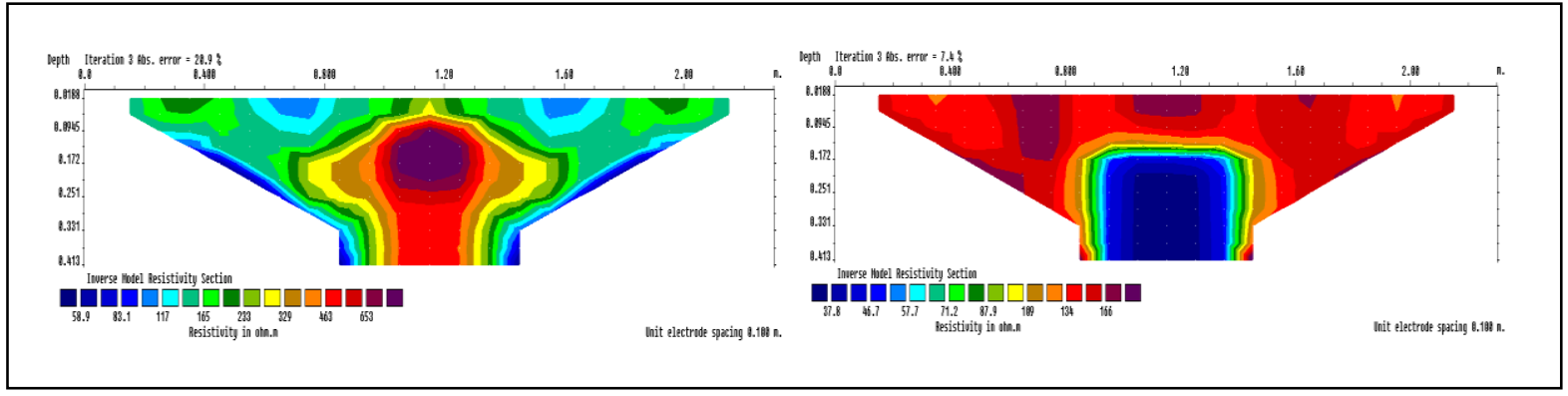

Gambar 4.3. Hasil pengolahan data Res2dinv pada Lintasan 4 dan Lintasan 5 kondisi akuifer cekung sebelum diberi air dan setelah diberi air dengan Konfigurasi Wenner

\subsection{Akuifer Berurat}

Hasil pengolahan dari software Res2dinv diperlihatkan pada Gambar 4.4. menunjukkan bahwa kondisi akuifer terletak di dua titik pada kedalaman $15-25 \mathrm{~cm}$ pada titik elektroda 7-10 dan 15-18 dengan warna citra biru muda sampai biru tua. Nilai resistivitas pada kondisi sebelum diberi air lebih besar dibandingkan setelah diberi air yaitu pada Lintasan 6 nilai resisitivitas minimum pada pemodelan ini $120,13 \Omega \mathrm{m}$ dan maksimum resistivitas sebesar 475,93

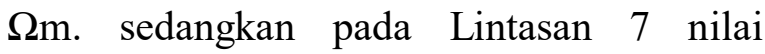
resisitivitas minimum pada pemodelan ini 39,48 $\Omega \mathrm{m}$ dan maksimum resistivitas sebesar 145,40 $\Omega \mathrm{m}$. Pada tampilan citra ini nilai resistivitas daerah akuifer lebih rendah dibandingkan daerah lainnya hal ini ditunjukkan dengan warna citra biru muda hingga pekat dikarenakan pada daerah ini kandungan airnya lebih banyak dibandingkan daerah lainnya. Pada lapisan tanah sekeliling akuifer terlihat adanya perbedaan citra warna, hal ini dikarenakan adanya perbedaan tingkat kelembaban pada tanah. Akuifer berurat yang dijumpai pada lapangan tidak selamanya sama dengan pemodelan yang dibuat, tatapi pada umumnya mempunyai pola yang sama yaitu adanya beberapa titik sumber air yang terpisah. Namun apabila dilakukan penelitian lebih lanjut titik-titik sumber air ini akan bertemu dan membentuk satu sumber air. 


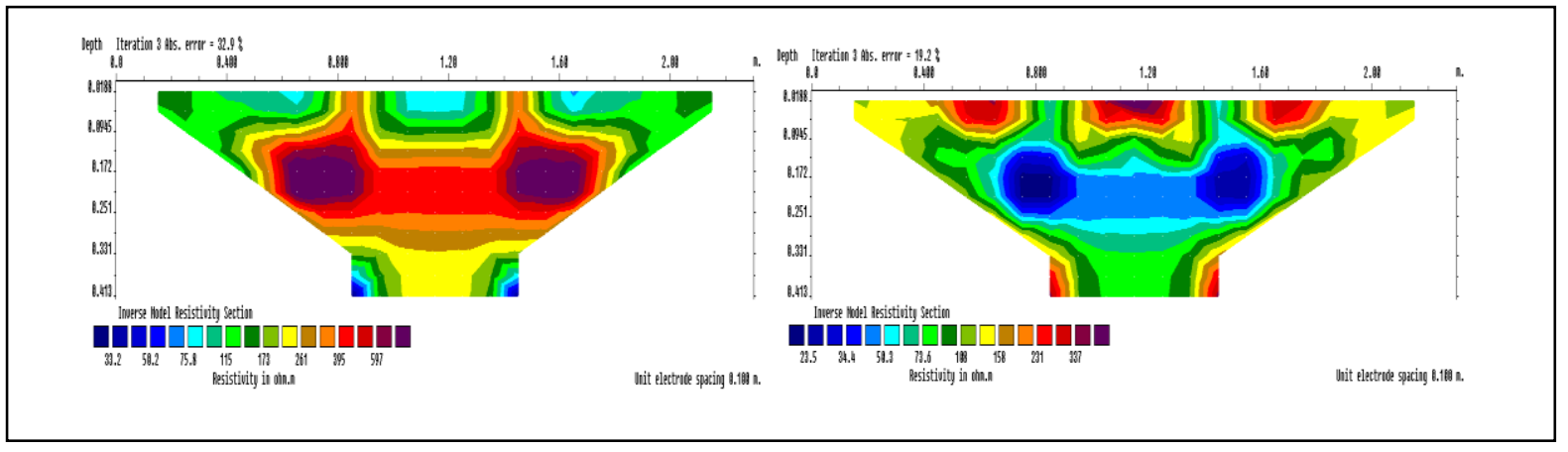

Gambar 4.4. Hasil pengolahan data Res2dinv pada Lintasan 6 dan Lintasan 7 kondisi akuifer beruratsebelum diberi air dan setelah diberi air dengan Konfigurasi Wenner.

\section{KESIMPULAN}

Adapun kesimpulan dari penelitian ini adalah:

1. Pemodelan citra akuifer flat dengan menggunakan metode geolistrik menghasilkan citra dengan dengan warna berbeda-beda yang menunjukkan kuantitas kandungan airnya.

2. Pemodelan citra akuifer cekung dengan menggunakan metode geolistrik menghasilkan citra akuifer terletak pada kedalaman 15-30 $\mathrm{cm}$ dengan warna biru.

3. Pemodelan citra akuifer berurat dengan menggunakan metode geolistrik diperoleh dua biru terpisah yang menunjukkan dua sumber air.

\section{DAFTAR PUSTAKA}

Geocis, 2016. Metode Geolistrik Tahanan Jenis (Resistivity).

http://geocis.indonetwork.co.id (diakses pada 5 Mei 2016)

Krussman, G.P. and Ridder, N.A., 1970. Analysis and Evaluation of Pumping Test Data. International Institude for Land Reclamation and Improvement, Wegeningnen.

Loke, M.H., 2000. Electrical imaging surveys for environmental and engineering studies. England:

Birmingham University. Prihastiwi, Fifi Erfiyanti., 2016. Identifikasi Akuifer Di Zona Patahan Opak Pasca Gempa Yogyakarta 2006 Dengan Metode Geolistrik Konfigurasi Schlumberger. S1 thesis, Universitas Negeri Yogyakarta. 